RASĀYAN J. Chem.

Vol. 14 | No. 2 |1297-1306| April - June | 2021 ISSN: 0974-1496 | e-ISSN: 0976-0083 | CODEN: RJCABP http://www.rasayanjournal.com http://www.rasayanjournal.co.in

\title{
PROSPECTS OF NANOTECHNOLOGY AS A TOOL TO MITIGATE COVID-19
}

\author{
G. Pandey ${ }^{1, \bigotimes}$, S. Bajpai ${ }^{2}$ and S. Tripathi ${ }^{3}$ \\ ${ }^{1}$ Department of Chemistry, SRM -IST, Delhi- NCR Campus, Ghaziabad, 201204, (UP) India \\ ${ }^{2}$ Department of Chemistry, Amity School of Applied Sciences, Amity University, \\ Lucknow, 226010 (UP) India \\ ${ }^{3}$ Department of Chemistry, Skyline Institute of Engineering and Technology, \\ Greater Noida, 201310, (UP) India \\ Corresponding Author: garimapandey.pandey8@gmail.com
}

\begin{abstract}
The epidemic of acute respiratory infection of coronavirus as COVID-19 has shaken up the world. At the time of writing on $15^{\text {th }}$ September 2020213 nations all around the globe have reported a total of 32,755,000confirmed cases of coronavirus COVID-19 that originated from Wuhan, China, with a death toll of 4.7 million deaths? The corona epidemic has posed a serious threat to the existence of mankind with global pressure on healthcare sectors. None of the aspects of the existence of societies is unaffected by COVID-19, be it jobs, industries, economy, education, societal, research sector, with rapidly mounting death tolls being a wake-up call for global health. It is very much necessary for the mankind that whole of the scientific world come together with new methods, technologies, medicines and vaccines to curb the spread of this deadly disease. Currently, there is no precise and accurate treatment method available for COVID-19, but a wide range of studies are going on exploring all the possible antiviral solutions. Meanwhile among various fields of science and technology nanotechnology has great potential and can play an important role by providing effective solutions for diagnosis, detection, sensing, treatment and protection against COVID-19. The nanoscale and large surface area of nanoparticles can be very effective in various stages of coronavirus treatment. The article aims to highlight the major prospective contributions and solutions that nanotechnology can fetch to alleviate the chronic COVID-19 pandemic.
\end{abstract}

Keywords: Nanotechnology, COVID-19, Nanosensors, Nanomedicine, PPE.

RASĀYAN J. Chem., Vol. 14, No.2, 2021

\section{INTRODUCTION}

We all knew that something like this will come. Ample alarming signals were pointing towards the possible threat of a viral or bacterial pandemic because of our unplanned urbanization, industrialization, animal trading chemical-based agriculture practices and un-scrutinized import and export activities. We failed to realize and recognize the warning signs through various viral outbreaks like swine flu, avian influenza, SARS, MERS in the last twenty years and ultimately were outplayed by the beautiful viral nanocreatures. ${ }^{1,2}$ Though experts around the globe have been scrutinizing the scenarios and were working on developing strategies to counter intended or accidental microbial explosion, we could not assure, rapid and effective implementation of these strategies. The novel coronavirus infectious disease labeled as (COVID-19) by WHO, was first reported on December 31st, 2019 in the Wuhan city of China. ${ }^{3,4}$ COVID19 was found to be caused by the SARS-CoV-2 virus. Coronavirus attacks the lower and upper respiratory tracts of patients with symptoms like flu-like fever, exhaustion, dry cough and breathing problems. ${ }^{5,6}$ Cases with no or very mild symptoms have also been reported which took around 14 days to reflect after the exposure to the virus, and it has also been found that an asymptomatic human may also shed the virus making people infected.

The existence graph of COVID-19 can be summarized into the following points: $:^{7-9}$

- Pneumonia of an unidentified cause detected in Wuhan, China on 31st December 2019.

Rasayan J. Chem., 14(2), 1297-1306(2021)

http://dx.doi.org/10.31788/ RJC.2021.1426271

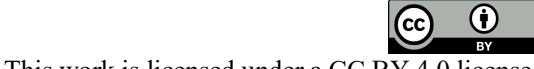

This work is licensed under a CC BY 4.0 license. 
RASĀYAN J. Chem.

Vol. 14 | No. 2 |1297-1306| April - June | 2021

- On February 11, 2020, WHO announced a name for this disease as coronavirus disease COVID19 ?

- The outbreak was affirmed as a public health crisis of international concern on 30th January 2020.

Since then, COVID-19 is taking countries under its effect in a very drastic manner. WHO is working round the clock to investigate the statistics, prepare and manage specialist systems, offer counseling and guidance, coordinate with nations and increase supplies. ${ }^{10-12}$

\section{Why use of Nanotechnology for COVID-19?}

This coronavirus pandemic is not the first challenge in front of the world and the continuous research for new technological developments and their deployment is the key tool to fight against it. Nano-based technological solutions can be utilized for the detection, treatment, and prevention of coronavirus. The subject of discussion is a question of the ability of nanoparticles to hinder the attachment of virus with the host cell ${ }^{9}$ and the solution comes in the form of hybridization of metal NPs with antiviral medicines resulting in the target-based precise delivery with enhanced efficiency. ${ }^{13-15}$ Viruses can be considered as very smart and proficient nanoparticles with a deception characteristic of hijacking and transmitting their genetic code into the target cell. These nanoscale viral particles when manhandled can lead to big havoc and devastation to mankind. Nanotechnology-based medical equipment can be of enormous help to healthcare professionals. Metal nanocomposites can be exceptionally helpful for the controlled and sustained release of medicines. ${ }^{16-19}$

The nanotechnology could be helpful against COVID-19 in four key phases

1. during the phase of diagnosis

2. during the phase of drug delivery in infected ones

3. during the phase of disinfection

4. during the phase of restraining the immune response of infected ones

Nano-inventions may well lend a hand in the following ways ${ }^{20-22}$

\section{Nanotechnology Solutions for COVID-19}

Nanotechnology has the potential to comprehensively contribute to the fight with COVID-19 because the specific characteristics of nanoparticles can render the pathogens inoperative before they entered the host cell. Nanotechnologists from all around the world are working round the clock to deal with this global health emergency. In the pursuit of a vaccine for COVID-19 continues, researchers working in the area of nanotechnology have joined the battle against it. The COVID-19 crisis has mustered the scientific community in such a challenging way like never before. ${ }^{23,24}$ Nanotechnology has diverse applications ranging from electronics, electrical, material sciences, chemical science, environmental, medical, and biological, textile engineering, and computational science, etc.

Table-1: Role of Nanotechnology for a Fight with COVID- 19

\begin{tabular}{c|c}
\hline Role & Solutions provided by Nanotechnology \\
\hline Detection & Nanosensors to detect pathogens \\
\hline Prevention & $\begin{array}{c}\text { Nanofibre based respirators } \\
\text { Nanomaterials based vaccines } \\
\text { Nanosols as disinfectants }\end{array}$ \\
\hline Treatment & $\begin{array}{c}\text { Nanomedicines Nanoparticle for drug } \\
\text { delivery }\end{array}$ \\
\hline
\end{tabular}

- A SiO2 and silver nanoparticles based anti-viral air filter was recently being developed ${ }^{15,25}$

- $\mathrm{TiO} 2$ and Ag nanoparticle-based solutions were being used for disinfecting streets in Italy ${ }^{26,28}$

- For maintaining transparency in testing and immunization processes, Quantum Materials Corp, a US-based Production Company proclaimed the production of a QDX HealthID block-chain supported COVID-19 immunity passpotrts. ${ }^{27}$ 
RASĀYAN J. Chem.

Vol. 14 | No. 2 |1297-1306| April - June | 2021

Table-2: Applications of Nanomaterials to Combat COVID- $19^{30}$

\begin{tabular}{c|c}
\hline Nanomaterial & Area of Application \\
\hline Metallic nanoparticles & Virus protected Surface coating \\
\hline Nanofibres & Equipment for facemask protection \\
\hline $\mathrm{Ag}$ and $\mathrm{Cu}$ oxide nanoparticles & Face masks \\
\hline $\mathrm{Copper}$ and iodine nanoparticles, \\
$\mathrm{SiO}$ and silver nanoparticles & $\begin{array}{c}\text { Virus inactive material for masks, filters, gowns, } \\
\text { shoe covers, and gloves }\end{array}$ \\
\hline $\mathrm{CeO}_{2}$ nanoparticles & Skin protection and decontamination treatment \\
\hline Electrospun PTFE nano-fibre & Respiratory filter (99.999\% efficiency) \\
\hline Polyvinylidene fluoride resin (PVDF) nano-fibers & Facemasks \\
\hline Nanofibres of polypropylene & Facemasks enclosed with pathogen collectors \\
\hline copper nanoparticles infused in polyester & For packaging paper and cardboards \\
\hline Polyamidoamine nanoparticles & antiviral Face masks with antiviral proprieties \\
\hline
\end{tabular}

\section{Nanosensors for Detecting COVID- 19}

Rapid and efficient diagnostics is the next step towards slowing the spread of COVID-19. Nanotechnology can provide rapid and cost-effective diagnostic methods with the help of nanosensors. The current testing methodology for COVID-19 involves the analysis of swabs through reverse transcription-polymerase chain reaction (RT-PCR) test. ${ }^{31-33}$ The use of nanoparticles could provide a more immediate 'on-site' test result. Field-effect transistors are graphene-based biosensing device which can be used as an alternative to RT-PCR test. Gold nanoparticles in combination with the appropriate receptor can be used in nano biosensors, to detect viral cells selectively.

Table-3: Nanosensors to detect COVID- 19

\begin{tabular}{|c|c|c|}
\hline Viruses & Sensor Type & Detection Speed \\
\hline \multirow{6}{*}{ SARS-CoV-2 } & Gold nanoparticles & 15 minutes $^{34}$ \\
\hline & $\begin{array}{l}\text { Polystyrene nanoparticles loaded with } \\
\text { lanthanides }\end{array}$ & 10 minutes $^{35}$ \\
\hline & Zinc ferrite nanoparticles & $\begin{array}{l}15 \text { minutes (RNA extraction and } \\
\text { RT-PCR process) }\end{array}$ \\
\hline & $\begin{array}{l}\text { Streptavidin-coated polymeric } \\
\text { nanoparticles }\end{array}$ & $60 \mathrm{~min}$ for entire diagnosis ${ }^{37}$ \\
\hline & $\begin{array}{c}\text { Magnetic nanoparticles with polyamino } \\
\text { ester coating }\end{array}$ & $\begin{array}{l}20 \text { minutes (purification and RT- } \\
\text { PCR process) }\end{array}$ \\
\hline & Nanoplasmonic resonance sensor & $6-10$ hours $^{39}$ \\
\hline $\begin{array}{l}\text { SARS-CoV-2 along with } \\
\text { other viruses infecting } \\
\text { the respiratory system }\end{array}$ & Nanopore target sequencing & 15 minutes $^{40}$ \\
\hline
\end{tabular}

\section{PPE Kits made from Nanomaterials}

World Health Organization has advised using personal protective equipment to check the spread of COVID-19 infection. But the face masks generally being used have their limitations in terms of durability, usage, and filtration capacity. ${ }^{41-43}$ Nanomaterials are also being utilized for producing personal protective equipment to control the spread of COVID-19. Nanofibres can be used to make reusable, durable, breathable fabrics for personal protective equipment, having the capability of catching nanoscale droplets. ${ }^{44}$ Graphene can be used in fabrics to produce lightweight, fire-resistant, UV radiation resistant PPEs which can block the microbes from transiting through. Silver nanoparticles can be highly useful and effective in this respect, with the capability of restricting the viruses through filters. ${ }^{45-47}$

Table-4: Personal Protective Equipment from Nanomaterials ${ }^{48}$

\begin{tabular}{c|c|c|c}
\hline PPE & Company & Product Name & Nanomaterial Used \\
\hline \multirow{4}{*}{ Masks } & Nexera Medical-Canada & $\begin{array}{c}\text { The Guardian masks- (reusable, } \\
\text { with valve, without valve) }\end{array}$ & $\begin{array}{c}\text { Blend of silver and copper } \\
\text { nanoparticles }\end{array}$ \\
\cline { 3 - 3 } & ESpin Technologies, Inc.- & $\begin{array}{c}\text { Defense Series-Respirator } \\
\text { masks }\end{array}$ & \\
\cline { 2 - 3 } & Surgical Masks- & Nanofibres \\
\hline
\end{tabular}


RASĀYAN J. Chem.

Vol. 14 | No. 2 |1297-1306| April - June | 2021

\begin{tabular}{|c|c|c|c|}
\hline & \multicolumn{3}{|l|}{ USA } \\
\hline & MVX Prime Ltd. & Self-cleaning MVX Nano Mask & $\begin{array}{c}\text { Titanium and silver zeolite } \\
\text { nanoparticles }\end{array}$ \\
\hline \multirow{3}{*}{ Gloves } & $\begin{array}{l}\text { TEXAMED }{ }^{\circledR} \text { GmbH- } \\
\text { Germany }\end{array}$ & PADYCARE® & silver nanoparticles \\
\hline & $\begin{array}{l}\text { MapaSpontex- United } \\
\text { Kingdom }\end{array}$ & Everyday Protect Gloves L & silver nanoparticles \\
\hline & $\begin{array}{l}\text { GAMA HEALTHCARE } \\
\text { LTD. }\end{array}$ & Chlorhexidine wash gloves & silver nanoparticles \\
\hline
\end{tabular}

\section{Nanotechnology-based Vaccine Candidates}

To win the fight against COVID-19, researchers all over the world are working day and night to develop a successful vaccine. The vaccine is generally an inactive variety of a virus that behaves as an antigen to prepare and guide our immune system to develop antibodies. ${ }^{49}$ During delivery, sometimes the vaccine loses its efficiency by breaks down prematurely before reaching the target spot. Nanomaterials have emerged as a perfect base for designing vaccines against viral infectious diseases. Viruses and Nanoparticles function at the same size range, and this unique attribute strengthens the role of nanotechnology in immune-engineering technologies and vaccine development. Nanotechnology can be beneficial in designing vaccines for COVID19 as nanomaterials can be a best-suited candidate for the delivery of antigens in target cells in the form of imitation to virus and as an adjuvant. ${ }^{50-53}$ Nanoparticles can disrupt the structure of coronavirus and can hinder their binding to the receptors and transmission in the human body. The inexorable increase in the number of COVID-19 cases all over the world laid the foundation for the amalgamation of nanotechnologies and vaccine candidates into human clinical trials. Nanoparticle-based vaccines have many advantages in terms of their cost-effectiveness, storage, largescale production and are safer as compared to live attenuated and in-activated strains. ${ }^{54,55}$ This encapsulation of vaccines protects them from decomposition and can make them more effective if decked up with target-specific molecules. Various vaccines based on nanotechnology are using mRNA, DNA, lipid and protein build-ups and are in various phases of human trial. ${ }^{56-58}$

Table-5: Vaccine Candidate based on Nanomaterials ${ }^{59}$

\begin{tabular}{|c|c|c|}
\hline Type of Vaccine & Name of the Developer Company & Status of Clinical Trial \\
\hline $\begin{array}{l}\text { Recombinant SARS-CoV-2 glycoprotein } \\
\text { nanoparticle }\end{array}$ & Novavax & Phase $1 / 2$ \\
\hline Lipid Nanoparticle encapsulated mRNA & $\begin{array}{l}\text { BioNJTech } \\
\text { FosumPharma } \\
\text { Pfizer }\end{array}$ & Phase $1 / 2$ \\
\hline Lipid Nanoparticle -nCoVsaRNA & Imperial College London & Phase 1 \\
\hline Lipid Nanoparticle encapsulated mRNA & Moderna/NIAID & Phase 3 \\
\hline LNPs combined with mRNA & $\begin{array}{c}\text { CanSino Biologics (China) } \\
\text { Precision NanoSystems (Canada) } \\
\text { University of Tokyo (Japan) }\end{array}$ & Pre-clinical \\
\hline $\begin{array}{l}\text { LNPs formulated with DPX platform, } \\
\text { containing peptides epitopes from SARS-CoV- } \\
\text { 2 S protein }\end{array}$ & IMV, Inc. (Canada) & Pre-clinical \\
\hline $\begin{array}{l}\text { LNPs formulated with recombinant S protein } \\
\text { and other epitopes from SARS-CoV-2 }\end{array}$ & $\begin{array}{c}\text { St. Petersburg Scientific Research } \\
\text { Institute of Vaccines and Serums } \\
\text { (Russia) }\end{array}$ & Pre-clinical \\
\hline $\begin{array}{l}\text { LNPs loading mRNA encoding functional } \\
\text { proteins from SARS-CoV-2 }\end{array}$ & $\begin{array}{l}\text { Translate Bio (United States) } \\
\text { Sanofi Pasteur (United States) }\end{array}$ & Pre-clinical \\
\hline $\begin{array}{l}\text { LNPs formulated with recombinant vesicular } \\
\text { stomatitis virus (rVSV) }\end{array}$ & BIOCAD (Russia) & Pre-clinical \\
\hline $\begin{array}{l}\text { A virus-like particle with features of SARS- } \\
\text { CoV-2 S protein obtruding from a protein } \\
\text { nanoparticle platform }\end{array}$ & Ufovax, LLC (United States) & Pre-clinical \\
\hline
\end{tabular}


RASĀYAN J. Chem.

Vol. 14 | No. 2 |1297-1306| April - June | 2021

\begin{tabular}{c|c|c}
\hline UQ 'S molecular clamp technology, & ViroclinicsXplore (Netherlands) & Pre-clinical \\
\hline $\begin{array}{c}\text { Recombinant vaccine containing COVID-19 S } \\
\text { proteins }\end{array}$ & LakePharma, Inc. (United States) & Pre-clinical \\
\hline $\begin{array}{c}\text { Recombinant vaccine using AdVac }{ }^{\circledR} \\
\text { technology }\end{array}$ & $\begin{array}{c}\text { Janssen Pharmaceuticals, Inc. } \\
\text { (Belgium) }\end{array}$ & Pre-clinical \\
\hline $\begin{array}{c}\text { LNPs loading mRNA encoding the receptor- } \\
\text { binding domain of SARS-CoV-2 S protein }\end{array}$ & $\begin{array}{c}\text { Fudan University (China) } \\
\text { Shangh JiaoTong University (China) } \\
\text { RNACureBiopharma (China) }\end{array}$ & \\
\hline
\end{tabular}

Nanotechnology for Drug Delivery

Researchers working in the area of nano-medicine have succeeded in constructing a range of nanosystems that can impersonate the high contagion rate and gene transfer capacity of viral vectors. In the perspective of nano-medicines various nanomaterials like dendrimer, micelles, liposomes, quantum dots, polymeric nanoparticles, carbon nanotube, and mesoporous silica nanoparticles have been designed and employed in various aspects of drug delivery. ${ }^{60,61}$ The exploitation of nanomaterials for drug delivery faces the challenge of decomposition of the virus-compound complex on dilution, which leaves the virus-free to replicate and grow. This restraint can be overcome by synthesizing specially designed nanoparticles having the ability to irreversibly curb the infectivity of the virus by destructing the virion. ${ }^{62,63}$ Nanocarriers can improve the competency of the delivery of immune-suppressants by precisely targeting immune cells, protecting the non-target cells reducing the dosage of the drug required, and likely side effects. Magnetic nanoparticles can be directed by the external magnetic field to particularly target the respiratory organs with viral infections. A nanoparticle can be used as a carrier to encapsulate nucleic acid encoding the antigen. Nanoparticles as nano-carriers offer stability can grant inherent, synchronized and targeted delivery of both adjuvant and antigen. ${ }^{64-66}$

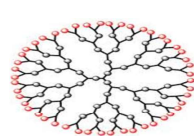

Dendrimer

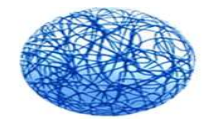

Polymeric Nanoparticles

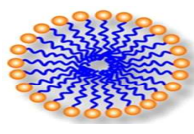

Miscelle

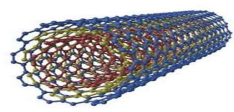

Carbon Nano Tube

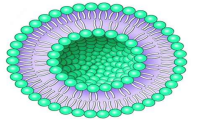

Liposome

Quantum Dot

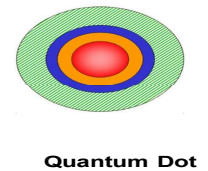

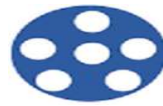

Mesoporous Silica Nanoparticles

Fig.-1: Applications of Nanomaterials to Combat COVID- 19

\section{Risk Assessment and Management}

At present, no cure for COVID-19 is available yet. But scientists all over the world are focused to develop a vaccine and a secure and efficient cure for COVID-19. The specific surface property of nanomaterials dramatically amplifies their reactivity, leading to extreme alterations in their toxic effects. Most of the risks associated with nanomaterials are inadequately analyzed. ${ }^{67,68}$ Experts all over the world have emphasized safety assessments and evaluation of the health and environmental effects of nanoproducts across their life cycle. Owing to the antimicrobial properties of silver and copper these metal nanoparticles along with other substituents are widely being used for disinfection and decontamination. A range of polymeric and inorganic nanoparticles are being explored as carriers for drug delivery and nano vaccines for curing and preventing the COVID-19 infection. ${ }^{69-71}$ Nanoparticles could induce harmful effects in humans, animals and environmental constitution. They can affect the immune system, central nervous system, gastrointestinal system, in humans, can get accumulated in organism, might cause noxious effects in aquatic ecosystems. ${ }^{72-75}$ During this COVID19 emergency, scientists should focus on 
RASĀYAN J. Chem.

Vol. 14 | No. 2 |1297-1306| April - June | 2021

analyzing the potential risks of nanomaterials being used for disinfection, prevention, treatment to suggest clear rules, regulations and guidelines to assure the safety of the creator, user and the environment.

\section{Future Prospectives}

The significance of nanotechnology in combating viral infections is not adequately being investigated. One of the potential perspectives of nanotechnology is exploiting nanomaterials to deal with the resistance generated because of the growth of a new viral strain due to shifts in peripheral protein sequence. ${ }^{76,77}$ Nanotechnology can be considered imperative in (i) creating nano-based sensors for designing rapid tests of COVID-19 $9^{78,79}$, and (ii) producing novel theranostic tools and nano-based medications. For the target-based and precise delivery of medicines in the ventilated patients, biodegradable nano-carriers can be of great help. ${ }^{80,81}$ Owing to the great surface characteristics of nanoparticles nano-based antimicrobial surfaces, packaging and coating materials, fabrics, personal protection equipment can be developed. ${ }^{82,83}$ Gold, silver and Ag-Cu nanoparticles can be explored to inhibit the viral penetration and spread and single-walled CNTs as nanocarriers for antiviral drugs across the cell membranes ${ }^{84-87}$ Magnetically routed Iron NPs might be used for precise targeting of respiratory organs of infected patients. ${ }^{88,89}$ Chloroquine and hydroxychloroquine can be complexed with $\mathrm{Cu}, \mathrm{Fe}, \mathrm{Zn}$, Ni nanoparticles for antiviral formulations. ${ }^{90-94}$ These are just a few of the possible research avenues to be explored further. Though numerous high-quality research is going on using metal nanoparticles as antimicrobial agents, still the concerns related to their low yield, toxicological apprehensions, ${ }^{95-97}$ costs, environmental effects and stability are restricting their marketing and broad acceptance. ${ }^{98-101}$ The insightful part being played by nanotechnology is irrefutable, but nanomaterials might lead to serious concerns about the health of the respiratory organs. Efficacious amalgamation therapeutic methods incorporating nano-medicine co-delivery schemes, though, can be a promising alternative in the fight against the diverse mutants of COVID-19. ${ }^{102-106}$

\section{CONCLUSION}

COVID-19 pandemic can be managed through the concurrent implementation of the key principles of early diagnosis and continuous monitoring. Early detection with consistent monitoring and targeting of COVID-19 cases may well aid the treatment and management of the patients, health workers, policemen, people related to essential services and the hot-spot areas as well. Therefore, we all should aim to find a cure for COVID-19, if not curable, we should focus on controlling the symptoms to improve the lives of those infected. The views expressed in this article are the perspectives and need to be worked on. The scientific community needs to research on developing antivirals derived from chloroquinone and hydroxychloro- quinine based metal nanomaterials. Exploring the uncharted anti-viral characteristics of nanomaterials may be an effective approach to combat the COVID-19 pandemic. The researchers working on nanomaterials must exploit nanoprinciples to face this continuing global health emergency.

\section{ACKNOWLEDGMENT}

I would like to show gratitude to the Dean, Deputy Registrar and Dean CL of SRM-IST, NCR Campus, my HOD and colleagues who provided insights, expertise and support that greatly assisted the research.

\section{REFERENCES}

1. L. Yu, Y. Tong, G. Shen, A. Fu, Y. Lai, X. Zhou, Y. Yuan, Y. Wang, Y. Pan and Z. Yu,Y.Li, T. Liu, H.Jiang, medRxiv, (2020), in Press, DOI:10.1101/2020.03.03.20030650

2. C. I. Paules, H. D. Marston and A. S. Fauci, JAMA,323, 707(2020), DOI:10.1001/jama.2020.0757

3. Q. Li, X. Guan, P. Wu, X. Wang, L. Zhou, Y. Tong, R. Ren, K.S.M. Leung, E.H.Y. Lau, J.Y. Wong, X. Xing, N. Xiang, Y. Wu, C. Li, Q. Chen, D. Li, T. Liu, J. Zhao, M. Liu, W. Tu, C.Chen, L.Jin, R.Yang, Q.Wang, S.Zhou, R.Wang, H.Liu, Y.Luo, Y.Liu, G. Shao, H.Li, Z.Tao, Y.Yang, Z.Deng, B.Liu, Z.Ma, Y.Zhang, G.Shi, T.TYLam , J.TWu, G.F.Gao,B.J. Cowling, B.Yang, G.M. Leung and Z.Feng, The New England Journal of Medicine, 382, 1199(2020), DOI:10.1056/NEJMoa2001316

4. D.S. I. Hui, E. Azhar, T.A. Madani, F. Ntoumi, R. Kock, O. Dar, G. Ippolito, T.D. McHugh, Z.A. Memish, C. Drosten, A. Zumla and E. Peterson, International Journal of Infectious Diseases.91, 264(2020), DOI:10.1016/j.ijid.2020.01.009 
RASĀYAN J. Chem.

Vol. 14 | No. 2 |1297-1306| April - June | 2021

5. S.P. Adhikari, S. Meng, Y.-J. Wu, Y.-P. Mao, R.-X. Ye, Q.-Z. Wang, C. Sun, S. Sylvia, S. Rozelle and H. Raat and H. Zhou, Infectious Diseases of Poverty.9, 29(2020), DOI:10.1186/s40249-02000646-X

6. D. Wang, B. Hu, C. Hu, F. Zhu, X. Liu, J. Zhang, B. Wang, H. Xiang, Z. Cheng, Y. Xiong, Y. Zhao, Y. Li, X. Wang and Z. Peng, JAMA,323, 1061(2020), DOI:10.1001/jama.2020.1585

7. WHO, World Health Organization, International Clinical Trials Registry Platform (ICTRP). Available online: $\mathrm{http}: / / \mathrm{www}$. who.int/ictrp/en/

8. Global Times China, Chinese Scientists Have Developed a New Weapon to Combat the Coronavirus. Available online: https://twitter.com/globaltimesnews/status/1244244793393217536

9. B. Cao, Y. Wang, D. Wen, W. Liu, J. Wang, G. Fan, L. Ruan, B. Song, Y. Cai, M. Wei, X. Li, J. Xia, N. Chen, J. Xiang, T. Yu, T. Bai, X. Xie, L. Zhang, C. Li and Y. Yuan, The New England Journal of Medicine,382,1787(2020), DOI: 10.1056/NEJMoa2001282

10. D. Baram-Pinto, S. Shukla, N. Perkas, A. Gedanken and R. Sarid, Bioconjugate Chemistry.20, 1497(2009), DOI: 10.1021/bc900215b

11. H. Bunje, S. Glotzer, Y. Li, P. Samori, T. Weil, S. N. Shmakov and P. S. Weiss, ACS Nano,14, 1213(2020), DOI: 10.1021/acsnano.0c01221

12. N. Cioffi, L. Torsi, N. Ditaranto, G. Tantillo, L. Ghibelli, L. Sabbatini, T. Bleve-Zacheo, M. D'Alessio, P. G. Zambonin and E. Traversa, Chemistry of Materials.17, 5255(2005), DOI: $10.1021 / \mathrm{cm} 0505244$

13. H. Palza, M. Nuñez, R. Bastías and K. Delgado, International Journal of Antimicrobial Agents, 51, 912(2018), DOI: 10.1016/j.ijantimicag.2018.02.007

14. Rapid Nano-Gold Tests Can Ease Pressure on Centralised Testing for COVID-19. Nano MagazineLatest Nanotechnology News 2020, Available online: https://nanomagazine.com/news/2020/3/26/rapid-nano-gold-tests-can-ease-pressure-on-centralised-testin g-forcovid-19

15. B. Udugama, P. Kadhiresan, H. N. Kozlowski, A. Malekjahani, M. Osborne, V. Y. C. Li, H. Chen, S. Mubareka, J. B. Gubbay and W. C. W. Chan, ACS Nano, 14, 3822(2020), DOI:10.1021/acsnano.0c02624

16. N. H. L. Leung, D. K. W. Chu, E. Y. C. Shiu, K.-H. Chan, J. J. McDevitt, B. J. P. Hau, H. -L. Yen, Y. Li, D. K. M. Ip, J. S. M. Peiris, S. Wing-Hong, M. L. Gabriel, K. M. Donald, J. C. Benjamin, Nature Medicine, 26, 1(2020), DOI:10.21203/rs.3.rs-16836/v1

17. Y. Han and P. Král, ACS Nano,(2020), in Press, DOI:10.1021/acsnano.0c02857

18. F. Perreault, A.F.de Faria, S. Nejati and M. Elimelech, ACS Nano. 9, 7226(2015), DOI: $10.1021 /$ acsnano.5b02067

19. Y.-N. Chen, Y.-H. Hsueh, C.-T. Hsieh, D.-Y. Tzou and P.-L. Chang, International Journal of Environmental Research and Public Health, 13,430(2016), DOI:10.3390/ijerph13040430

20. M. C. Duch, G. R. S. Budinger, Y. T. Liang, S. Soberanes, D. Urich, S. E. Chiarella, L.A. Campochiaro, A. Gonzalez, N.S.Chandel,M.C.Hersam,et al., Nano Letters, 11, 5201(2011), DOI: $10.1021 / \mathrm{nl} 202515 \mathrm{a}$

21. H. Kariwa, N. Fujii and I. Takashima, Dermatology, 212(Suppl.1), 119(2006), DOI: $10.1159 / 000089211$

22. M. Eggers, M. Eickmann, J. Zorn, Infectious Diseases and Therapy, 4, 491(2015), DOI:10.1007/s40121-015-0091-9

23. X. Hang, H. Peng, H. Song, Z. Qi, X. Miao, W. Xu, Journal of Virological Methods. 222, 150(2015), DOI: $10.1016 /$ j.jviromet.2015.06.010

24. G. Ungur and J. Hr uza, RSC Advances, 7, 49177(2017), DOI:10.1039/C7RA06317B

25. V. Krähling, D. A. Stein, M. Spiegel, F. Weber and E. Mühlberger, Journal of Virology, 83, 2298(2009), DOI: 10.1128/JVI.01245-08

26. https://statnano.com//news/67531/CoronavirusNanotech-Surface-Sanitizes-Milan-withNanomaterials-Remaining-Self-sterilized-for-Years

27. https://www.ledgerinsights.com/nanotechnology-blockchain-covid-19-immunity-passports/ 
RASĀYAN J. Chem.

Vol. 14 | No. 2 |1297-1306| April - June | 2021

28. M. C. Sportelli, R. A. Picca, N. Cioffi, Trends in Analytical Chemistry, 84, 131(2016), DOI: $10.1016 / j \cdot \operatorname{trac} .2016 .05 .002$

29. https://www.nanowerk.com/nanotechnology-news2/newsid=54893.php

30. R. G. Kerry, S. Malik, Y. T. Redda, S. Sahoo, J. K. Patra, S. Majhi, Nanomedicine: Nanotechnology, Biology and Medicine, 18, 196(2019), DOI:10.1016/j.nano.2019.03.004

31. Sona Nanotech. Sona Develops Rapid Screening Test for Coronavirus; Sona Nanotech: Halifax, Canada, 2020.

32. https://www.who.int/dg/speeches/detail/who-director-general-s-opening-remarks-at-the-mediabriefing-on-covid-19---16-march-2020

33. H. M. Mansour, Y. S. Rhee, X. Wu, International Journal of Nanomedicine. 4, 299(2009), DOI: $10.2147 /$ ijn.s4937

34. Z. Li, Y. Yi, X. Luo, N. Xiong, Y. Liu, S. Li, Journal of Medical Virology, 92, 1518(2020), DOI: $10.1002 /$ jmv. 25727

35. Z. Chen, Z. Zhang, X. Zhai, Y. Li, L. Lin, H. Zhao, B. Lun, P. Li, L. Yu, Y. Wu, G. Lin, Analytical Chemistry, 92(10)7226(2020), DOI:10.1021/acs.analchem.0c00784

36. S. B. Somvanshi, P. B. Kharat, T. S. Saraf, S. B. Somwanshi, S. B. Shejul, K. M. Jadhav, Materials Research Innovations, 24,1 (2020), DOI:10.1080/14328917.2020.1769350

37. X.Zhu, X.Wang, L.Han, T.Chen, L.Wang, H.Li, S.Li, L. He, X.Fu, S.Chen, X. Mei, H.Chen, Y. Wang, medRxiv, (2020), DOI:10.1101/2020.03.17.20037796

38. Z.Zhao, H.Cui, W.Song, X.Ru, W.Zhou, X.Yu, bioRxiv, (2020), DOI:10.1101/2020.02.22.961268

39. L.Huang, L.Ding, J.Zhou, S.Chen, F.Chen, C.Zhao, J.Xu, W, Hu, J.Ji, H., Xu and G.L. Liu,Biosensors and Bioelectronics, 171,112685 (2021), DOI:10.1016/j.bios.2020.112685

40. M.Wang, A.Fu, B.Hu, Y.Tong, R.Liu, Z.Liu, J.Gu, B. Xiang, J.Liu, W. Jiang, G. Shen, W. Zhao, D. Men, Z. Deng, L. Yu, W. Wei, Y.Li and T.Liu,. Small,16(32), 2002169(2020), DOI: $10.1002 / \mathrm{smll} .202002169$

41. A.Chang, A.H.Schnall, R.Law, A.C.Bronstein, J.M.Marrafa, H.A.Spiller, Morbidity and Mortality Weekly Report, 69(16), 496(2020)

42. CDC. Coronavirus Disease 2019 (COVID-19)- Transmission, Centers for Disease Control and Prevention, 2020, Available from: https://www. cdc.gov/coronavirus/2019-ncov/prevent-gettingsick/how-covid-sprea ds.html.

43. M. Conlon, (2014), https://patents.google.com/patent/WO2014143039A1/en

44. F.Lustenberger,(2016), https://patents.google.com/patent/US9446547B2/en

45. S.P.Deshmukh, S.M.Patil, S.B.Mullani, S.D.Delekar. Materials Science \& Engineering, C, 97, 954(2019), DOI:10.1016/j.msec.2018.12.102

46. Z.Y.Huo, X.Xie, T.Yu, Y.Lu, C.Feng, H.Y.Hu, Environmental Science \& Technology, 50, 7641(2016), DOI:10.1021/acs.est.6b01050

47. C.Balagna, S.Perero, F.Bosco, C.Mollea, M.Irfan, M.Ferraris, Open Ceramics, 508, 145283(2020), DOI: $10.1016 /$ j.oceram.2020.100006

48. E.Campos, A.S.Pereira, J.L.de Oliveira, L.B.Carvalho, M.Guilger-Casagrande, R.de Lima, L.Fraceto, Journal of Nanobiotechnology, 18,125(2020), DOI:10.1186/s12951-020-00685-4

49. S.D.Xiang, A.Scholzen, G.Minigo, C.David, V.Apostolopoulos, P.L.Mottram, M. Plebanski, Methods, 40(1)1(2006), DOI:10.1016/j.ymeth.2006.05.016

50. W.C.W.Chan, ACS Nano, 14(4)3719(2020), DOI:10.1021/acsnano.0c02540

51. G.A.Sautto, G.A.Kirchenbaum, R.A.Diotti, E.Criscuolo, F.Ferrara., Journal of Immunology Research, 2019,5890962, (2019), DOI:10.1155/2019/5890962

52. T.J.Moyer, A.C.Zmolek, D.J.Irvine. The Journal of Clinical Investigation,126(3),799(2016), DOI: $10.1172 / \mathrm{JCI} 81083$

53. P.Lung, J.Yang, Q.Li, Nanoscale,12,5746(2020), DOI:10.1039/C9NR08958F

54. M.A.Liu., Vaccines (Basel),7(2), 37(2019), DOI:10.3390/vaccines7020037

55. M.D.Shin, S.Shukla, Y.H.Chung, V.Beiss, S.K.Chan, O.A.Ortega-Rivera, D.M.Wirth, A.Chen, M.Sack, J.K.Pokorski, N.F.Steinmetz., Nature Nanotechnology,15(8), 646(2020), DOI: $10.1038 / \mathrm{s} 41565-020-0737-y$ 
RASĀYAN J. Chem.

Vol. 14 | No. 2 |1297-1306| April - June | 2021

56. A.S. Espeseth, P.J. Cejas, M.P. Citron, D.Wang, D.J.DiStefano, C.Callahan, NPJ Vaccines, 5, 16 (2020), DOI:10.1038/s41541-020-0163-Z

57. C.Zhang, G.Maruggi, H.Shan, J.Li, Frontiers in Immunology, 10, 594(2019), DOI: 10.3389/fimmu.2019.00594

58. EpiVax. EPV-CoV19: HCW vaccine. EpiVax, Inc.Informatics and Immu-nology, 2020, https://epivax.com/pipeline/epv-cov19. Accessed 16 June 2020

59. G.Chauhan, M.J. Madou, S.Kalra, V.Chopra, D.Ghosh,S.O.Martinez-Chapa , ACS Nano, 14(7),7760(2020), DOI: $10.1021 /$ acsnano.0c04006

60. M.Lim, A.Z.M.Badruddoza, J.Firdous, M.Azad, A.Mannan, T.A.Al-Hilal, C.-S.Cho, M.A.Islam. pharmaceutics, 12(1), 30(2020), DOI:10.3390/pharmaceutics12010030

61. S.Aghamiri, S.Talaei , A.A.Ghavidel, F.Zandsalimi, S.Masoumi, N.H.Hafshe-jani and V.Jajarmi, Journal of Drug Delivery Science and Technology, 56(A), 101533(2020), DOI: $10.1016 /$ j.jddst.2020.101533

62. L.A.Lane, X.Qian, A.M.Smith andS.Nie, Annual Review of Physical Chemistry, 66, 521(2015), DOI: 10.1146/annurev-physchem-040513-103718

63. M.Swaminathan, N.K.Sharma, Antimicrobial Activity of the Engineered Nanoparticles Used as Coating Agents, In: L.M.T.Martínez, O.V.Kharissova, B.I.Kharisov, editors, Handbook of Ecomaterials Cham: Springer International Publishing, 2019, p.549-63, DOI:10.1007/9783-31968255-6 1

64. S.L.Mitchell and E.E.Carlson, ACS Infectious Diseases, 4(10), 1432(2018), DOI: $10.1021 /$ acsinfecdis. 8 b00138

65. G.Berrecoso, J.Crecente-Campo andM.J.Alonso., Drug Delivery and Translational Research, 10(3),730(2020), DOI:10.1007/s13346-020-00745-0

66. A.A. Rabaan, S.H. Al-Ahmed, S.Haque, R.Sah, R.Tiwari, Y.S.Malik, K.Dhama, M. I. Yatoo, D. K. Bonilla-Aldana and A. J. Rodriguez-Morales., Le infezioni in Medicina, 28(2), 174(2020)

67. V. Valdiglesias and B. Laffon, Nanotoxicology, 14(8), 1013(2020), DOI: $10.1080 / 17435390.2020 .1780332$

68. V.S.Sivasankarapillai, A.M.Pilla, A.Rahdar, A.P.Sobha, S.S.Das,A.C.Mitropoulos, M.H.Mokarrar and G.Z.Kyzas, Nanomaterials, 10(5), 852(2020), DOI:10.3390/nano10050852

69. G. Nikaeen, S. Abbaszadeh and S. Yousefinejad, Nanomedicine (Lond), 15(15),1501(2020), DOI: $10.2217 / \mathrm{nnm}-2020-0117$

70. OECD 2015, Testing Programme of Manufactured Nanomaterials, Organisation for Economic CoOperation and Development, Available from: https://www.oecd.org/ chemicalsafety/nanosafety/testing-programme-manufactured-nanomaterials.htm.

71. A. Adamcakova-Dodd, M. M. Monick, L.S. Powers, K.N.Gibson-Corley and P.S.Thorne, Particle and Fibre Toxicology, 12, 30(2015), DOI:10.1186/s12989-015-0105-5

72. T. J. Baker, C. R. Tyler and T. S. Galloway, Environmental Pollution,186, 257(2014), DOI: 10.1016/j. envpol.2013.11.014

73. Y. Liu, A. A. Gayle, A. Wilder-Smith and J. Rocklov, Journal of Travel Medicine, 27 (2)2(2020), DOI: $10.1093 / \mathrm{jtm} / \mathrm{taaa} 021$

74. WHO, 2019, Principles and Methods to Assess the Risk of Immunotoxicity Associated with Exposure to Nanomaterials (Environmental Health Criteria: n. 244), Geneva: World Health Organization

75. WHO, 2020, Coronavirus Disease (COVID-19) Situation Report-130, World Health Organization. Available from: https:// www.who.int/docs/default-source/coronaviruse/situationreports/20200529covid-19-sitrep-130.pdf?sfvrsn=bf7e7f0c_4

76. L. Rao, R. Tian and X. Chen, ACS Nano, 14(3), 2569(2020), DOI:10.1021/acsnano.0c01665

77. D. Lauster, S. Klenk, K. Ludwig, S. Nojoumi, S. Behren, L. Adam, M. Stadtmüller, S. Saenger, S. Zimmler, K. Hönzke, L. Yao, U. Hoffmann, M. Bardua, A. Hamann, M. Witzenrath, L.E. Sander, T.Wolff, A.C. Hocke, S. Hippenstiel, S.De. Carlo, J.Neudecker, K. Osterrieder, N.Budisa, R. R. Netz, C. Böttcher, S.Liese, A. Herrmann and C.P. R. Hackenberger, Nature Nanotechnology, 15(5), 373(2020), DOI:10.1038/s41565-020-0660-2 
RASĀYAN J. Chem.

Vol. 14 | No. 2 |1297-1306| April - June | 2021

78. E.Ong, M.U.Wong, A.Huffman and Y.He, Frontiers of Immunology, 11,1581(2020), DOI: $10.3389 /$ fimmu.2020.01581

79. B.Polyak and B.Cordovez, Nanomedicine, 11(3), 189(2016), DOI: 10.2217/nnm.15.192

80. C.L.Ventola, Progress in Nanomedicine: Approved and Investigational Nanodrugs, Pharmacy and Therapeutics, 42(12),742(2017)

81. J.M.Caster, A.N. Patel, T.Zhang andA.Wang, Wiley Interdisciplinary Reviews, Nanomedicine and Nanobiotechnology, Jan 9,1(2017), DOI:10.1002/wnan.1416

82. V.P.Zhdanov, Current Opinion in Colloid \& Interface Science, 41, 95(2019), DOI: $10.1016 /$ j.cocis.2018.12.002

83. G. Berrecoso, J. Crecente-Campo and M. J. Alonso, Drug Delivery and Translational Research, 10,730(2020), DOI: $10.1007 / \mathrm{s} 13346-020-00745-0$

84. S. Angioletti-Uberti, npj Computational Materials, 3,48(2017), DOI:10.1038/s41524-017-0050-y

85. C. J. Gordon, E. P. Tchesnokov, J. Y. Feng, D. P. Porter and M. Götte, The Journal of Biological Chemistry, 295(15), 4773(2020), DOI:10.1074/jbc.AC120.013056

86. World Health Organization: Coronavirus Disease Pandemic, https://www.who.int/emergencies/diseases/novel-coronavirus-2019

87. H. Huang, C. Fun, M. Li, H.-L. Nie, F.-B. Wang, H. Wang, R. Wang, J. Xia, X. Zheng, X. Zuo and J. Huang, ACS Nano, 14, 3747(2020), DOI:10.1021/acsnano.0c02618

88. V.S.Sivasankarapillai, A.M.Pillai, A.Rahdar, A.P.Sobha, S.S.Das, A.C.Mitropoulos, M.H.Mokarrar and G.Z.Kyzas, Nanomaterials, 10, 852(2020), DOI:10.3390/nano10050852

89. M.T.u.Qamar, A.Rehman, U.A.Ashfaq, M.Q.Awan, I.Fatima, F.Shahid and L.-L.Chen, PLOS ONE 15(12), e 0244176(2020), DOI:10.1371/journal.pone.0244176

90. J. F. Pontes, and A. Grenha, Nanomaterials, 10, 183(2020), DOI:10.3390/nano10020183

91. G. Kampf, D. Todt, S. Pfaender and E. Steinmann, Journal of Hospital Infection, 104, 246(2020), DOI: $10.1016 / j$.jhin.2020.01.022

92. T.H.Sucipto, S.Churrotin, H.Setyawati, T.Kotaki, F.Martak and S.Soegijanto, Journal of Tropical Infectious Disease, 6, 84(2017), DOI:10.20473/ijtid.v6i4.3806

93. G.Pandey, Oriental Journal of Chemistry, 34,2838(2018c), DOI:10.13005/ojc/340622

94. H.-H.Fan, L.-Q.Wang, W.-L.Liu, X.-P.An, Z.-D.Liu, X.-Q.He, L.-H.Song and Y.-G. Tong, Chinese Medical Journal, 133(9), 1051(2020), DOI:10.1097/CM9.0000000000000797

95. K.Phopin, N.Sinthupoom, L.Treeratanapiboon, S.Kunwittaya, S.Prachayasittikul, S. Ruchirawat and V.Prachayasittikul, EXCLI Journal. 15, 144(2016), DOI:10.17179/excli2016-101

96. C.A.Devaux, J.-M.Rolain, P.Colson and D.Raoult, International Journal of Antimicrobial Agents, 55(5),105938 (2020), DOI:10.1016/j.jijantimicag.2020.105938

97. D. Guo, Virologica Sinica, 35, 253(2020), DOI:10.1007/s12250-020-00204-7

98. S.Al-Halifa, L.Gauthier, D.Arpin, S.Bourgault and D.Archambault, Frontiers in Immunology,10, 22 (2019), DOI:10.3389/fimmu.2019.00022

99. G.Pandey, Environmental Technology and Innovation. 11, 299(2018a), DOI:10.1016/j.eti.2018.06.012

100. G.Pandey, Rasayan Journal of Chemistry, 11,942(2018b), DOI:10.31788/RJC.2018.1133031

101. Z.Zhu, X.Wang, Y.Yang, X.Zhang, K.Mu, Y.Shi, C.Peng, Z.Xu and W.Zhu, ChemRxiv. in press, (2020), DOI:10.26434/chemrxiv.11959323.v1

102. https://www.news-medical.net/news/20210315/The-role-of-nanotechnology-in-the-fight-againstCOVID-19.aspx

103. D.Yang, International Journal of Nanomedicine, 16,623(2021), DOI:10.2147/IJN.S296383

104. F.Vahedifard and K. Chakravarthy, Emergent Materials, Feb(2021), DOI:10.1007/s42247-02100168-8

105. N.S. Ghosh and R. Singh, Rasayan Journal of Chemistry, 14(1), 486(2021), DOI: $10.31788 /$ RJC.2021.1416130

106. Susilawati, M.Hanifuddin, Y.P. Gultom, Rasayan Journal of Chemistry, 12(3), 1043(2019), DOI: 10.31788/RJC.2019.1235166

[RJC-6271/2020]

1306

NANOTECHNOLOGY AS A TOOL TO MITIGATE COVID-19

G. Pandey et al. 